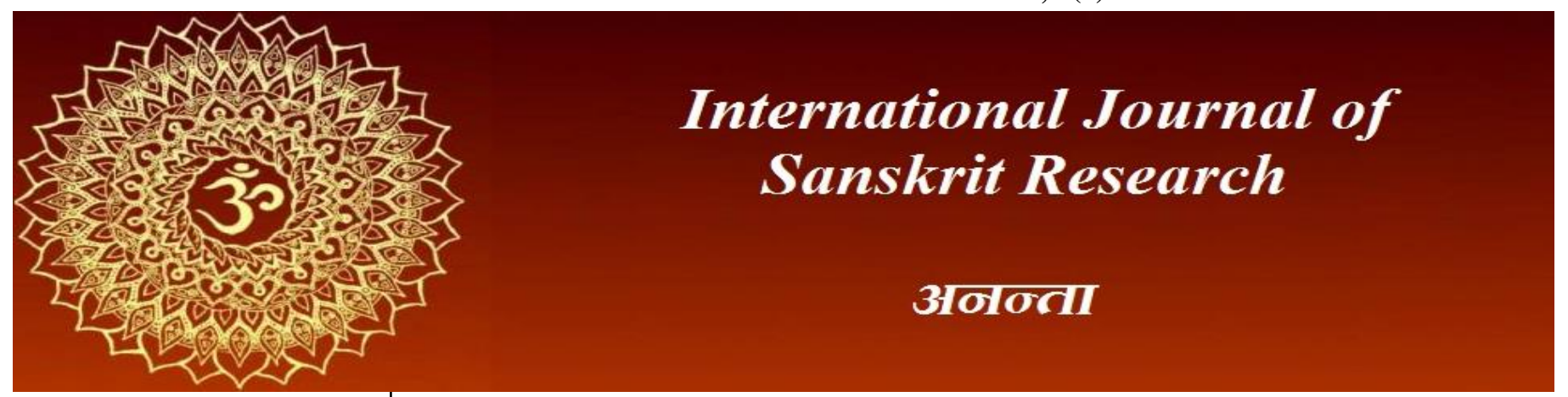

ISSN: 2394-7519

IJSR 2020; 6(5): 276-778

(C) 2020 IJSR

www.anantaajournal.com

Received: 09-06-2020

Accepted: 12-08-2020

Sabita Dash

Research Scholar,

Assistant Teacher Govt High

School, Department of Sanskrit

Utkal University, Bhubaneswar,

Odisha, India

Corresponding Author:

Sabita Dash

Research Scholar,

Assistant Teacher Govt High

School, Department of Sanskrit

Utkal University, Bhubaneswar,

Odisha, India

\section{Personality and its development in Veda}

\section{Sabita Dash}

DOI: https://doi.org/10.22271/23947519.2020.v6.i5e.1176

\section{Abstract}

Personality is the combination of characteristics or qualities that form an individual's distinctive character. At present, personality degradation is a global serious problem. The entire social atmosphere looks to be charged with the ambitions of unethical, immoral and unspiritual nature. Today's modern formal system of education is producing only money making machines ignoring the development of virtuous qualities and resulting in the development of negative personality traits. It is said that education in India was started during Vedic period. This system was centered to give importance for the development of personality achieved through Gurukula system, a center which provides practices, natural and appropriate environment, lessons on right conduct and teaching based on life, character and ideals of great person. In Vedic education one's personality was developed through self-realization and selfrespect. The end goal was to build self-awareness. In the present study, we should summaries the theories of personality and their practical application for the development of one 'personality.

Keywords: personality, panchakoshas, triguna, purusartha, gurukula

\section{Introduction}

The term personality has been derived from the Latin word "Persona" that was associated with Greek theatre in ancient times. Persona was meant a mask which the Greek actors commonly used to wear before their faces when they worked on stage. According to the concept of mask, personality was thought to be the effect and influence which the individual wearing a mask left on the audience. Hence, personality is the combination of characteristics or qualities that form an individual's distinctive character. But at present, personality degradation is a global serious problem. In the age of science, it is now so glaring that instead of developing a scientific attitude in life, people all over the World today are getting much more narrow, prejudiced and irrational. Must unscientific and irrational things are being said and done in the name of science. The political horizons of the country look very hazy and political shylocks seem determined to cut a piece of flesh from the sacred body of the mother India to fulfil their selfinterest and achieve their political aspirations. The entire social atmosphere looks to be charged with the ambitions of unethical, immoral and unspiritual nature. Today's modern formal system of education is producing only money making machines ignoring the development of virtuous qualities and resulting in the development of negative personality traits. It is said that education in India was started during Vedic period. This system was centered to give importance for the development of personality achieved through Gurukula system, a center which provides practices, natural and appropriate environment, lessons on right conduct and teaching based on life, character and ideals of great person. In Vedic education one's personality was developed through self-realization and self-respect. The end goal was to build self-awareness.

The present topic "Personality and its development in Veda" can be studied under two major heads

(A) Theoretical aspects of personality

(B) Practical aspects of personality 
(A) Theoretical aspects of personality-can be discussed under three sub heads

(a) The Panchakoshas theory

(b) The Purusartha theory

(c) The Triguna theory

(a) The Panchakoshas theory: provides a framework for fivefold holistic self-development.

Table 1: The five koshas (cell -unit of life) are the five sheaths of human personality

\begin{tabular}{|c|c|c|}
\hline Sheath name & Nourished by & Function \\
\hline Annamaya & food & physical \\
\hline Pranamaya & bio-energy & psychological \\
\hline Manamaya & education & mentological \\
\hline Vijanamaya & ego & intellectual \\
\hline Anandamaya & emotions & spiritual \\
\hline
\end{tabular}

(b) The Purusartha theory: indicates four objects of life.

1. Rightfulness or dharma embraces every type of righteous conduct, covering every aspects of life, both religious and secular.

2. Prosperity or artha means looking after one's material and social needs and translates into earning money, social recognition, power or its equivalent.

3. Rightful desires or kama implies sensual pleasures

4. Salvation or moksha is the realization of one's own self. The removal of Avidya (ignorance) is moksha, which is the aim of life and must be sought by every human being.

(c) The Triguna Theory:

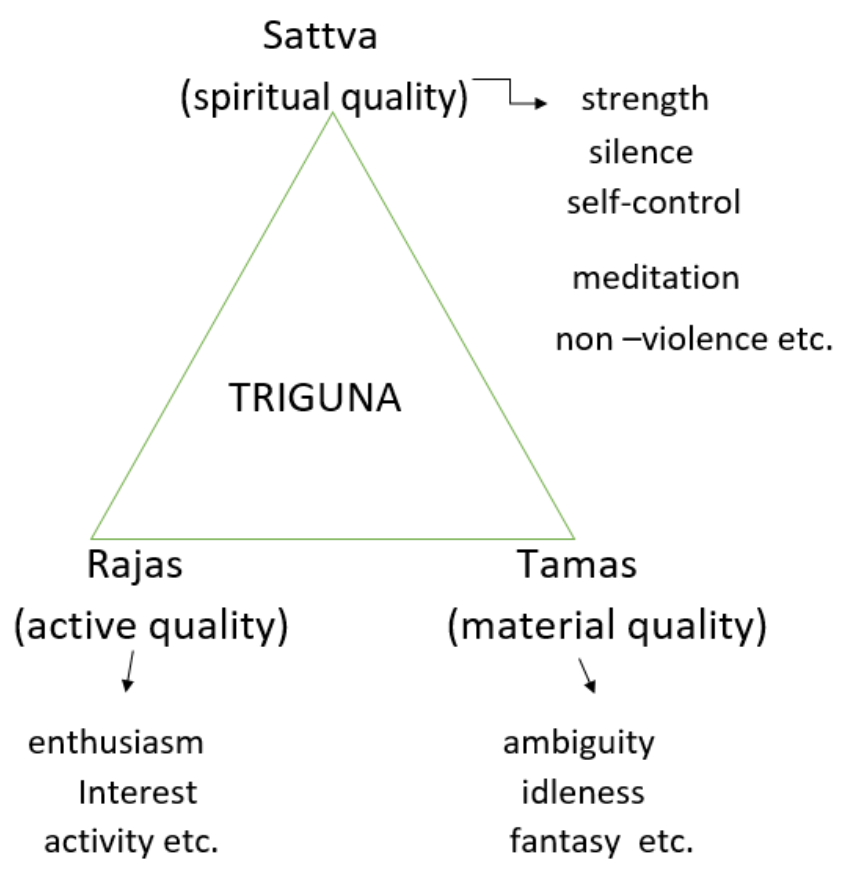

(B) Practical aspects of personality-can be discussed under following sub heads

(a) Training to promote good manner

(b) Purification and control of inner senses

(c) Practice of meditation

(d) Integration of four margas

(e) Search for a perfect Guru

(f) Self realisation

(g) Right company or Satsanga

(h) Gurukula education system (a) Training to promote good manner: Dress makes the man. Manners make the gentleman. Appreciation, constructive criticism, humour and tolerance are good manners. Flattery, cynicism, ridicule and vulgarism are bad manners.

(b) Purification and control of inner senses: According to Veda, Niskama karma is the cause of mental purification. Sakama karma creates attachment which increases mental impurities. Desire, anger, greed egoism etc. are lower types of emotions in the psychological layer of personality and they must be controlled. Upasana, Japa, charity, yajna, yoga and other such spiritual disciplines are all meant for purification of personality.

(c) Practice of meditation: For this purpose, one has to dive deep into his interest, life is more to give when one starts searching within himself. It makes the mind one-pointed, inward and then finally leads to the centre of consciousness, where peace, happiness and bliss reside.

(d) Integration of four margas: All the four margas i.e rajyoga (vision), gyan yoga (enlightenment), bhakti yoga (devotion) and karma yoga (action) are revealed through the individual letter V,E,D and A respectively. This implies that person should reach the level of 'sthithpragyan' when he/she completely controls his/her mind. A stressful mind would often lead to wrong decision making. Hence, it is needed to master the mind.

(e) Search for a perfect Guru: Veda proclaims for a sadguru, the learned Master. Before a disciple goes to a guru, he should have already read a lot of literature on religion and practiced different methods therein. Observing the qualities of the student right path is shown by the Guru to advance on the ladder of personality developed.

(f) Self-realisation: Personality includes body, sense organs, mind, intellect and the self. Personality integration requires self realisation. Disorgansation or disorder of vrittis leads to disintegration of personality.

(g) Right company or Satsanga: Satsang basically means being in the company of sat (truth). Company of falsehood always leads to destruction of body and soul.

(h) Gurukula education system: There was no institutionalized teaching in the Vedic days. There were teachers and they ran their own schools. It can be deduced from what we learn that monitor system prevailed and senior students did the job of assistant teachers. It was perhaps the best method of application for what they learn from their teachers. Such institutions were known as Gurukuls. The students, rich or poor used to go and live until they completed their education. The students had to live a very disciplined life. "Learning by doing" was perhaps one of the prescribed teaching methods. In this way, there institutions manufactured responsible citizens having strong personality for the society.

\section{Conclusion}

From the above study, we may conclude that different theories of personality development were the foundation of personality and personality development through vedic Psycholosy areas such as satsang, leaving bad companion, mental purification, good manners integration of emotions are the need of the present time. Education in Vedic era and the way of teaching was proper to accumulate material and especially spiritual knowledge. By re-establishing vedic culture, we can lead to a class of properly educated person who can ignite to the whole to be wisely developed one.

\section{Referance}

1. Chauhan SS. Advanced Education Psychology. 
2. Bhattacharya, Narendranath, Bharat Itihase vaiadik Yug, School of Vedic Studies 1998.

3. Radhakrishna S. Brahma Sutra, the Philosophy of Spiritual Life. Greenwood Press 1960.

4. Eight Upanisads, Tr by Swami Gambirananda 1, Advaita Ashram 1998.

5. Swami Prabhrupada, Bhaktivedanta AC. The science of self-Realization. The Bhaktivedanta Book Trust, 24 ${ }^{\text {th }}$ printing, January 2014.

6. Apte VS. The Students Sanskrit- English Dictionary, Motilal Banarasidass, Delhi 1963.

7. Keith AB, Religion and Philosophy of the Vedas and Upanishads, Oxferd 1925. 